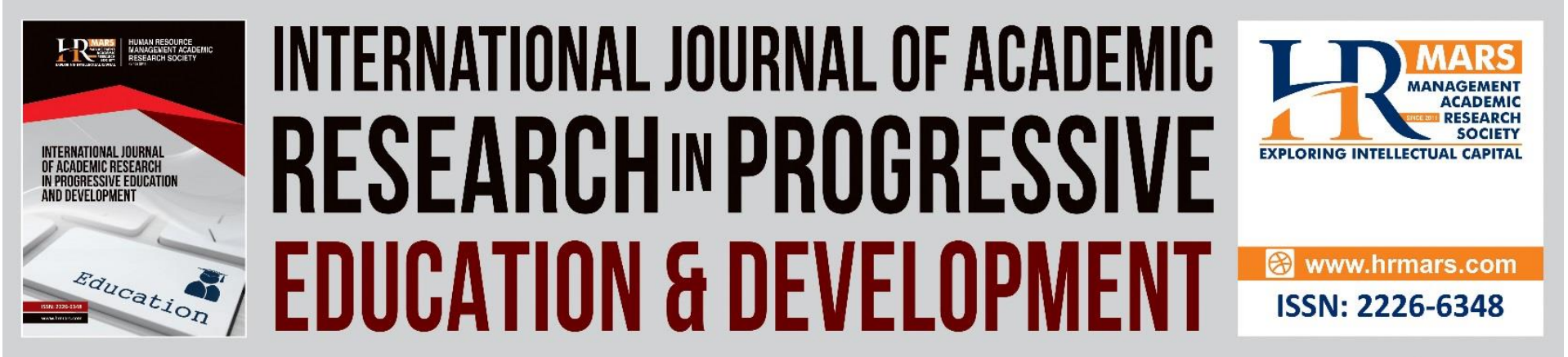

\title{
Mental Health Among Malaysian University Students Amidst Lockdown
}

Nalini Arumugam, Vemel (Resh) Ramasamy, Puspalata C Suppiah \& Malar Velli Segarmurthy

To Link this Article: http://dx.doi.org/10.6007/IJARPED/v10-i2/10596

DOI:10.6007/IJARPED/v10-i2/10596

Received: 16 May 2021, Revised: 20 June 2021, Accepted: 11 July 2021

Published Online: 23 July 2021

In-Text Citation: (Arumugam et al., 2021)

To Cite this Article: Arumugam, N., Ramasamy, V. (Resh), Suppiah, P. C., \& Segarmurthy, M. V. (2021). Mental Health Among Malaysian University Students Amidst Lockdown. International Journal of Academic Research in Progressive Education and Development, 10(2), 1081-1095.

Copyright: (C) 2021 The Author(s)

Published by Human Resource Management Academic Research Society (www.hrmars.com)

This article is published under the Creative Commons Attribution (CC BY 4.0) license. Anyone may reproduce, distribute, translate and create derivative works of this article (for both commercial and non-commercial purposes), subject to full attribution to the original publication and authors. The full terms of this license may be seen

at: http://creativecommons.org/licences/by/4.0/legalcode

Vol. 10(2) 2021, Pg. 1081 - 1095

Full Terms \& Conditions of access and use can be found at http://hrmars.com/index.php/pages/detail/publication-ethics 


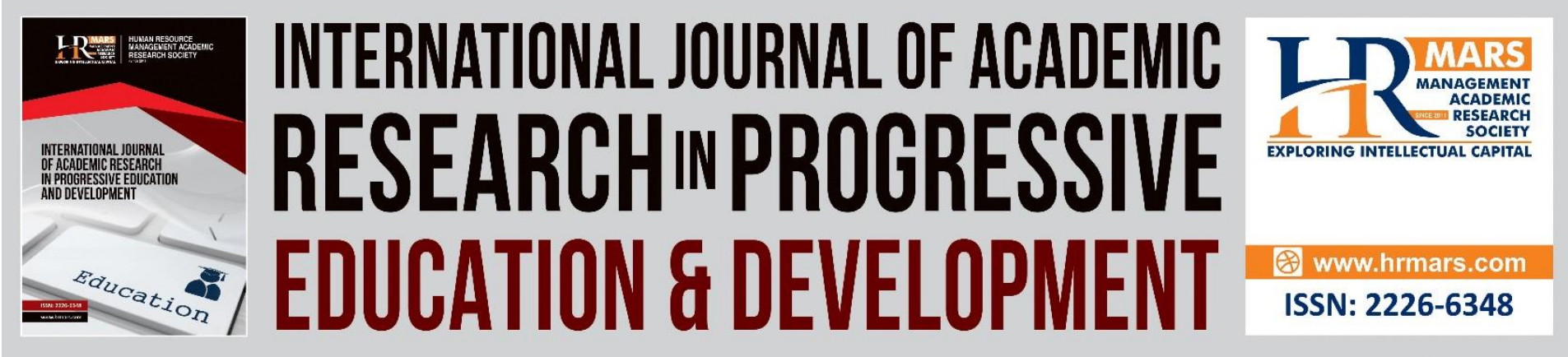

\title{
Mental Health Among Malaysian University Students Amidst Lockdown
}

\author{
Nalini Arumugam ${ }^{1}$, Vemel (Resh) Ramasamy², Puspalata C \\ Suppiah $^{3} \&$ Malar Velli Segarmurthy ${ }^{4}$ \\ ${ }^{1 \& 3}$ Academy of Language Studies, Universiti Teknologi MARA, Shah Alam, Selangor, \\ Malaysia, ${ }^{2}$ Flinders University, College of Nursing and Health Sciences, Disability and \\ Community Inclusion, Adelaide, South Australia, Australia, ${ }^{4}$ Planning Division of Ministry of \\ Health, Putrajaya, Malaysia. \\ Email:nalini@uitm.edu.my
}

\begin{abstract}
Covid-19 has caused world-shaking adversity around the globe. The pandemic has not only become a global health threat and inflicted morbidity status but equally been detrimental to mental health of human civilization. In order to encompass and rein the transmission of the virus, Malaysia including other countries around the globe enforced a nationwide lockdown. The current research aims to explore psychological distress among university students residing in Malaysia during the lockdown. 300 university students from local universities both private and public were asked to complete a questionnaire. The questions were centered on dealing with symptoms of depression, anxiety and stress coupled with experiences engaging in an online learning process. The results indicated that Covid-19 outbreak has increased students' levels of stress and anxiety. This is more prevalent in both male and female students who obtained a lower GPA score. Whilst home environment in the presence of their family were seen to support students to feel safe and less anxious, it did not however contribute to coping and managing their academic performance effectively. Staying connected with friends was seen to have helped students manage their academic endeavors better. As the universities have opted to continue with remote learning and it remains uncertain when face to face learning would recommence policymakers and practitioners should be guided by mental health professionals to support students appropriately and meaningfully.
\end{abstract}

Keywords: Private and Public University; COVID-19 Pandemic, Lockdown, Mental Anguish

\section{Introduction}

The world is in the middle of a severe acute respiratory syndrome called coronavirus pandemic or commonly known as COVID-19. Many countries implemented lock down in order to curb the spreading of this virus. Abdullah et al (2020) attributed stress with emotional and physical tension arose from any incident that intimidates one. As a precautionary step, the Malaysian government announced 'movement control order' (MCO) whereby everyone was 
advised to stay indoor to prevent transmission (Sani, 2020). Many organizations started to practice 'work-from-home policy'.

In Malaysia, the present lockdown affects people differently with regards to their profession and age especially students who are confined to home, online learning and assessments (Hidayu \& Vasudevan, 2020). The United Nation's Educational, Scientific, and Cultural Organization (UNESCO) reported that the catastrophic calamity has impacted more than one billion students in 129 countries globally (2020). As a result, many universities around the world have temporarily been closed and shifted to emergency remote teaching (ERT) through various online platforms which added to the anxiety and precarious nurture of higher education among students. With the extension of Movement Control Order (MCO), university students were disproportionately affected as many lived in hostels provided by their institutions while some temporarily rented private houses as they had to decide whether to leave the city and return to live with parents or family (Mian \& Khan, 2020).

\section{Background}

The synchronous (teaching and communicating with students in real time online) and asynchronous (recorded lectures or posted assignments online) added to the compounding challenges, especially for students with internet unavailability and poor connectivity (Lowenthal et al., 2020). Moreover, students were also deeply concerned of the uncertainty surrounding their studies, examinations, graduation, and job security post-graduation (Ahmed et al., 2020). Cao, et al (2020) conducted research among medical school undergraduates in China revealing that $2.7 \%$ of them had moderate level of stress and $0.9 \%$ experienced severe anxiety (Cao et al., 2020). Institutions of higher education were advised to transition all face-to-face classes to digital online modes of teaching and learning. Being confined in-doors with minimal face to face social interaction throughout was arduous as many experienced increased stresses as result of the pandemic. Despite being at home with their family, many students indicated experiencing increase in psychological distress due to the lockdown. According to Elmer et al (2020), the manifestations of stress, anxiety, loneliness and depression among students were amplified post the COVID-19 crisis (Elmer et al., 2020). Hidayu and Vasudevan (2020) echoed that lack of friendships can lead to depression, anxiety and stress. Besides, the examination-related anxiety had significant positive association with psychiatric problems among students (Abdullah et al., 2020). Shahzad et al (2020) reported that students in Malaysia are constantly faced with examination anxiety and stress, and this situation continuously occur at certain timing throughout the study process. They struggle to achieve a balanced state due to a myriad of curricular and extracurricular duties taking form of assignments, sports and on-going assessments (Shahzad et al., 2020). Likewise, Cao et al (2020) indicated that close to $25 \%$ of their respondents experienced anxiety symptoms which aligned with the increased concerns pertaining to academic delays. This condition worsened with the recent global Covid-19 outbreak, which impacted the mental state of many students in higher learning institutions in the country.

A worldwide survey conducted by YoungMinds (2020) during the pandemic revealed that $83 \%$ of the students concurred that the life-threatening Covid-19 exacerbated their existing mental health conditions due to interference and disruptions with daily routines and limited social interactions. Within a short time span, the pandemic has dramatically 
transformed the lives of the university students especially due to the sudden encounter with online learning. During this time, some students' academic activities were impeded because of their socioeconomic background resulting in anxiety (Cao et al., 2020). Also, with the closure of universities, some students were forced to cease their research projects (Zhai \& $\mathrm{Du}, 2020)$. All these had affected them emotionally and academically. The problem is more apparent in the rural areas where students faced a lot of difficulties to join online sessions. Dhawan (2020) claimed that online learning offers benefits in autonomous learning and developing new skills, yet it can be challenging to underprivileged students whose access to online learning is restricted. Other arguments related to online pedagogy are issues pertaining to affordability, learning pedagogy flexibility, and policy (Dhawan, 2020). Besides, some students in higher learning institutions had difficulty staying online during lessons and discussions as it takes up much of their mobile data (Agha, 2020). Although the Malaysian government was very supportive and provided the students with free $1 \mathrm{~GB}$ data, getting access to good internet connectivity was problematic to some students (Rashid et al., 2020). The students were not able to attend classes and carry out discussions with their lecturers and classmates through the Internet and because of this, their studies were affected.

This study aims to examine the psychological impact of confinement among Malaysian university students pertaining to their online learning. To the best of our knowledge, the agony experienced by students in higher education institutions during COVID-19 has not been widely reported or researched within Malaysia. Most of the studies that have been conducted investigated the impact of Covid-19 focusing on medical staff, health care workers and general public. (De Brier et al., 2020; Luo et al., 2020). Thus, the present research aims to extend the current literature by examining the psychological stress among university students in Malaysia during the Covid-19 lockdown. Additionally, it is hoped that the findings of this study could support policymakers and practitioners in designing appropriate and effective 'mental health management' that could help lessen the anxiety level of the affected students. The following research questions informed this research endeavor:

\section{Research Questions}

Q1. What is the level of mental health of students during national lockdown?

Q2. Is there any significant difference of level of stress between male and female students?

Q3. Is there any relationship between students' mental health and academic performance? 


\section{Conceptual Framework}

\section{INDEPENDENT VARIABLES}

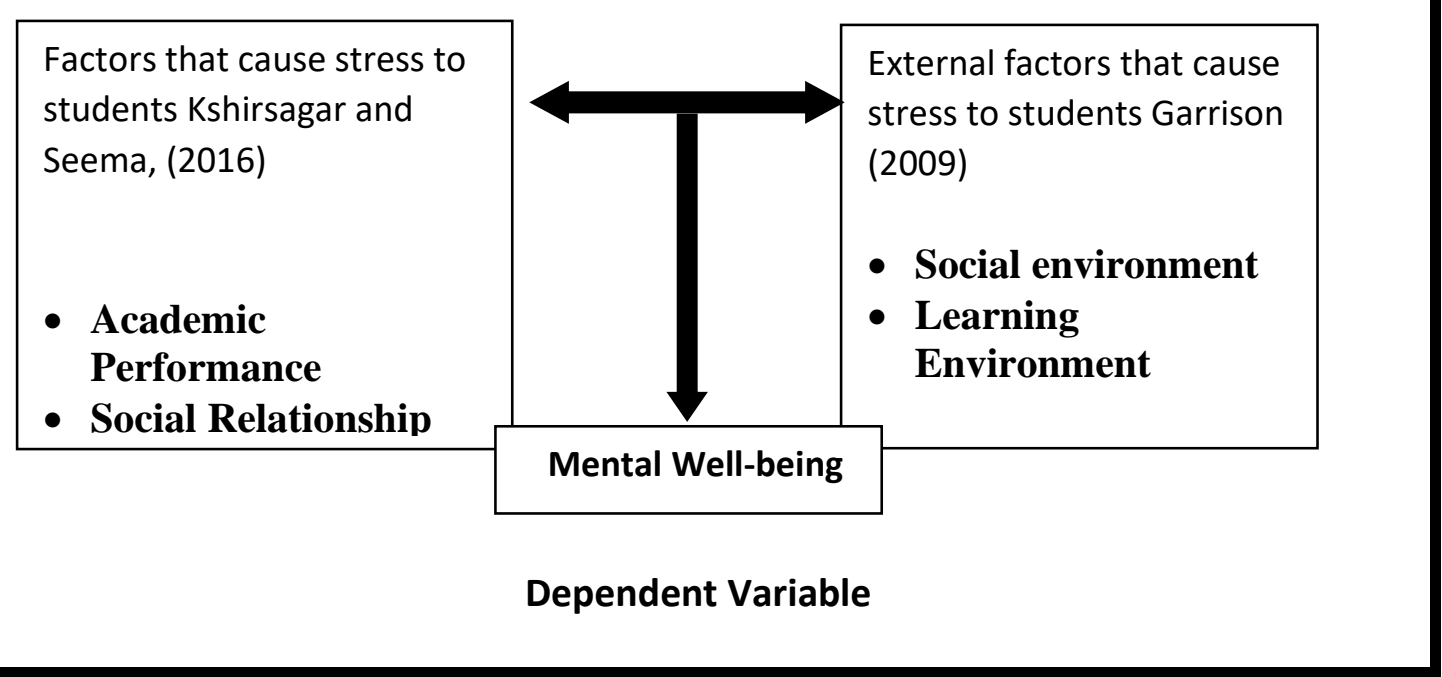

Figure 1: Proposed Framework for the Incorporation of Mental Wellbeing of University Students

The conceptual framework for the study is drawn from Kshirsagar and Seema (2016) on causes of mental stress among students and Garrison (2009) on external factors influencing students mental wellbeing for online learning methods (Garrison, 2007). Kshirsagar and Seema (2016) posit that academic performance, social relationship and financial constraints bring stress to students though their stress independently related to their mental and physical elements. They also emphasized that in this competitive world, university students need to maintain a good CGPA till the end of completion of the degree and this pressures them the most (Kshirsagar \& Seema, 2016). The students may find friendship in university. The pandemic has isolated everyone including university students. Lack of social interaction and physical presence can lead to high levels of frustration, pessimism, disengagement towards the instruction from the facilitator and lower capacity of learning ability (Gorsky \& Blau, 2009). Financial constraints too contribute to students' stress. As higher education has become so expensive and this poses another stress on parents and students especially those who can't afford paying college fees.

The Community of Inquiry framework by Garrison (2007) postulates that social environment and learning environment are crucial in students' mental wellbeing. When social engagement and physical presence are higher, learners have the ability and be equipped to discern information and instruction effectively, ameliorating their learning experience as a whole (Garrison, 2007). Lack of social interaction and physical presence can lead to high levels of frustration, pessimism, disengagement towards the instruction from the facilitator (Gorsky \& Blau, 2009). The online classrooms lack face-to-face interaction and absence of face-to-face interaction, and opportunities for socializing and social distancing not only subjugate the fun of learning but also instigate feelings of isolation and despair among students (Abdullah et al., 2020). 
Moreover, online competencies lead to a higher reliance on nonsynchronous methods of communication which shapes the effectiveness of instructors and the students' experience. Due to the pandemic, poor preparedness led to time constrains to accustom to new e-tools and environments (Roddy et al., 2017). At times when a university experiences stress, he/she doesn't know the reason of stress. Therefore, this study aims to investigate the cause of mental stress among university students. Both Kshirsagar and Seema (2016) and Garrison (2007) reported on students' mental wellbeing and the causes of stress. Therefore, an amalgamation of these in eliciting university students' mental wellbeing during pandemic isolation will be beneficial and significant for students, instructors to understand students' situation, curriculum developers and parents (Garrison, 2007)

\section{Methodology}

A quantitative design was utilized for the study to gather numerical data. Ethical approval was not mandated by the Academy of Language Studies, Universiti Teknologi MARA prior to commencement of the research. Despite that, ethical guidelines were closely informed by Vanclay et al (2013) to preserve the researchers' moral obligations to participants. Recruitment of participants took place between $2^{\text {nd }}$ of April to $30^{\text {th }}$ of June 2020 . Data collection was primarily conducted by the second author (NA). Participants were provided with an information sheet delineating the study's undertakings. Informed consent was obtained in written format. A total of 300 students from Malaysian public and private universities participated in the study. Participants were required to complete an online questionnaire. The questionnaire was adapted from Abdullah et al. (2020) and distributed to participants via Google forms. There were three sections in the questionnaire. Section $A$ elicited demographic profile of the participants, Section B dealt with questions relating to their mental health while Section $C$ obtained information about participants' stress levels during lockdown. All questions in Sections B and C were presented in a Likert Scale. Data was analyzed via SPSS $\vee 2$. and was performed by the first (NA) and second author (VRR). Independent Samples Test, Anova and correlational analysis were undertaken. Discussions were had with the third (PCS) and fourth author (VCS) pertaining to the data analytical process, where consensus was established amongst all four authors (Abdullah et al., 2020).

\section{Results \& Discussion}

There were $74.3 \%$ female and $25.7 \%$ male participants who participated in this study. A total of $89.1 \%$ of the participants derived from public universities, while the rest were situated from private universities in Malaysia. Most of the participants (90.3\%) accounted for undergraduate students with the remaining $9.3 \%$ and $0.4 \%$ reflecting diploma and postgraduate level students respectively.

\section{Research Question 1}

\section{What is the level of mental health of students during national lockdown?}

Cao et al (2020); YoungMinds (2020) indicated that Covid-19 pandemic may impact mental health in the form of direct threats to the individual's physical and mental health through precautionary efforts. For example, life-threatening diseases (Cao et al., 2020; Young, 2020). 
INTERNATIONAL JOURNAL OF ACADEMIC RESEARCH IN PROGRESSIVE EDUCATION AND

DEVELOPMENT

Vol. 10, No. 2, 2021, E-ISSN: 2226-6348 @ 2021 HRMARS

Table 1: Mental Health of Students during Lockdown

\begin{tabular}{|c|c|c|c|}
\hline No & Questions & Mean & $\begin{array}{c}\text { Std. } \\
\text { Deviation }\end{array}$ \\
\hline 1 & I always feeling tired & 3.33 & 0.98 \\
\hline 2 & I have trouble in falling or staying asleep & 3.16 & 1.11 \\
\hline 3 & I have little interest or no interest in anything & 3.06 & 1.19 \\
\hline 4 & I feel bad about myself & 3.04 & 1.20 \\
\hline 5 & I always feel down \& hopeless & 2.85 & 0.97 \\
\hline 6 & I have trouble concentrating on things such as reading & 2.84 & 1.11 \\
\hline 7 & newspaper or watching television & 2.81 & 1.19 \\
\hline 8 & I always think that I am a failure & 2.79 & 0.99 \\
\hline 9 & I move slowly so that other people will notice me & 2.52 & 1.04 \\
\hline 10 & I have poor appetite for the whole day & 2.41 & 0.93 \\
\hline
\end{tabular}

The descriptive statistics in Table 1 shows the frequency of university students' mental health. The table shows that majority of the students agreed that they are feeling weary with the highest mean $(M=3.33)$. They also shared that they have trouble in falling asleep with the mean $(M=3.16)$ followed by students having little interest or no interest in anything $(M=3.06)$. Stults-Kolehmainen and Sinha (2014) signaled that people who experience fatigue and trouble getting sleep are indicative of stressors associated to poor physical health. This finding is consistent with Veena and Shastri (2016) who signposted that if stress is not managed carefully, one may experience insomnia and excessive worrying (Stults-Kolehmainen \& Sinha, 2014; Veena \& Shastri, 2016).

Students problematizing themselves is the next highest mean with the $(M=3.04)$. When asked if students felt down and hopeless, only a small group of students agreed to the item with the mean (2.85), having trouble concentrating on task they are engaged in $(M=$ 2.83) and often attributing themselves as a failure $(M=2.81)$. Feelings of hopelessness is an impending factor for instigating and perpetuating depressive symptoms (Baptista et al., 2014; Boulton \& O'Connell, 201). A few of the students uttered that they spoke softly to prevent others from hearing them $(M=2.79)$ while $(M=2.52)$ agreed that they move slowly so that other people will not notice them. This could be correlated with diminished sense of selfesteem. Liu et al (2015) indicated that improved self-efficacy and self-management is pivotal in addressing depression.

The lowest ranking was having poor appetite reflected by the mean ( $M=2.41)$. Students' appetite was not affected during this period with the exception, of a small minority. The results showed, although majority of the participants were undergoing stress, their appetite was uncompromised which was reported by Yau and Potenza (2013). During lockdown, majority of the participants relocated from their temporary home/hostels to their parents' residence. They experienced significant psychological distress whereby participants were seen reporting an increase in anxiety since the commencement of the lockdown. This result contradicts Cao et al. (2020) findings where less than $4 \%$ of students reported moderate levels of anxiety during the Covid-19 pandemic. In light of this, it is important to consider the social determinants of health in a given country/locality/setting to discern the unique and 
DEVELOPMENT

Vol. 10, No. 2, 2021, E-ISSN: 2226-6348 @ 2021 HRMARS

intersectional challenges. In this case, Malaysia as a nation could benefit from improvement with student support and management in times of crisis.

\section{Students' Stress Learning in Isolation}

Majority of the participants concurred that lockdown stressed them for varied reasons, some of which that was difficult to discern. This concurs with Qiu et al (2020) and Wang et al. (2020) who pointed out that Covid-19 has caused immense stress among citizens, especially the student populace. This item was recorded the highest mean with $(M=3.54)$ in this study (refer to Table 2). This was followed by the item indicating online classes also stressed students reflecting a mean value of $(M=3.51)$. This finding was affirmed by Raj and Fatima (2020) who postulated students were distressed as they were unprepared nor anticipated the rapid transition to remote modes of learning which was undoubtedly foreign to them.

Table 2: Students' stress level

\begin{tabular}{|l|c|c|}
\hline & Item & Mean \\
\hline 1 & During lockdown, I am stressed for no reason & 3.54 \\
\hline 2 & Online classes cause stress & 3.51 \\
\hline 3 & I am stressed studying for my course & 3.30 \\
\hline 4 & Stress can make me miss my online class & 3.29 \\
\hline 5 & I am stressed to complete my assignment & 3.27 \\
\hline 6 & When I am stressed, I shared with people around me & 3.22 \\
\hline 7 & I can notice when people struggle with stress & 3.20 \\
\hline 8 & I know how to manage my stress very well & 2.92 \\
\hline
\end{tabular}

For the items "Stress can make me miss my online class", and "I am stressed to complete my assignment" indicated a high mean value with $(M=3.30)$ and $(M=3.29)$ respectively. This was in accord with researchers Reddy et al. (2018) advocated, that it is inevitable for students to escape from academic stress as it is a part and parcel of life, especially when preparing for examinations and assignment submissions.

Participants agreed that when they are stressed, they shared their mental strain with the people around them to as a way to destress $(M=3.27)$. As a result of their own experiences, they were highly attuned discerning when their peers are were struggling with stress $(M=3.22)$. When institutions of higher learning switched from any face-to-face to online classes, students experienced isolation in social networks as well as physical constraints such as unsupervised and solitary times using monitor screens. Elmer et al (2020) postulated that socially isolating and unfitting to customary ways of learning and engaging has accentuated feelings of isolation and loneliness.

A number of participants $(M=3.20)$ shared at times they were stressed without unexplainable reasons. The least number of participants $(M=2.92)$ were able to manage their stress level. This could be due to lockdown which has stripped off their natural attributes of social entity. Collectively, participants indicated that were stressed during lockdown. When students experience heightened levels of stress it can interfere with their academic performance. 
DEVELOPMENT

Vol. 10, No. 2, 2021, E-ISSN: 2226-6348 @ 2021 HRMARS

\section{Research Question 2}

Is there any significant difference of level of stress between male and female students?

Stress is an ongoing issue routinely evidenced among the life of students. Environmental threats and foreign conditions are some challenges that have been known to affect the stress level of university students (Siraj et al., 2014). The results are illustrated in table 3.

Table 3: Independent Samples Test of students' mental stress during lockdown by gender

\begin{tabular}{|c|c|c|c|c|c|}
\hline Students' mental stress during lockdown & Male & 78 & 3.24 & .66 & .11 \\
\cline { 2 - 7 } & Female & 222 & 3.13 & .65 & .08 \\
\hline
\end{tabular}

Table 3 depicted male students $(M=3.24, S D=.66)$ reported no significant mean difference in comparison to female students $(M=3.13, S D=.65), t(110)=.88, p>.05$. It was concluded gender does not have any influence on students' mental stress during lockdown. All students as a collective experienced unprecedented level of stress and depression. The finding was incongruent with Calvarese (2015) who showed a significant difference between males and females concerning their reactions to stress, where female students experienced higher levels of stress than their male counterparts. Whilst this was the case in Calvarese's study, it was not in this study.

Table 4: Students' Mental Stress Level and Causes

\begin{tabular}{|c|c|c|c|c|c|c|c|}
\hline \multicolumn{2}{|c|}{} & $\begin{array}{c}\text { Status of } \\
\text { students' } \\
\text { mental } \\
\text { health }\end{array}$ & $\begin{array}{c}\text { Lockdown } \\
\text { stresses } \\
\text { me for no } \\
\text { reason }\end{array}$ & $\begin{array}{c}\text { Online } \\
\text { classe } \\
\text { s } \\
\text { cause } \\
\text { stress }\end{array}$ & $\begin{array}{c}\text { Unabl } \\
\text { e to } \\
\text { focus } \\
\text { on } \\
\text { online } \\
\text { classe } \\
\text { s }\end{array}$ & $\begin{array}{c}\text { Inadequa } \\
\text { te study } \\
\text { facilities }\end{array}$ & $\begin{array}{c}\text { Fear of } \\
\text { doing } \\
\text { badly } \\
\text { in } \\
\text { exam }\end{array}$ \\
\hline $\begin{array}{c}\text { Status of } \\
\text { students' } \\
\text { mental health }\end{array}$ & $\begin{array}{c}\text { Pearson } \\
\text { Correlation }\end{array}$ & 1 & .72 & .71 & .52 & .70 & .70 \\
\hline Missing & Sig (2-tailed) & & .000 & .000 & .000 & .000 & \\
\hline $\mathrm{N}$ & & & 300 & 300 & 300 & 300 & 300 \\
\hline
\end{tabular}

Table 4 presents the results between students' mental stress level and the causes. Results showed that there was a high positive association between students' mental health and inadequate study facilities with $(r=.703, p<.05)$ as well as fear of doing badly in examination $(r=.703, p<.05)$. The findings concurred with Rehman et al (2020) who claimed students that relocated from hostels to their parent's abode faced challenges such as lack of facilities in the form internet connection and lack of private space to work on their assignments. This undoubtedly created a lot of unwanted tension and turbulence in their lives (Rahman, 2020).

Further analysis showed that there was a moderate positive correlation between students' mental health and ability to focus on online classes with $(r=.523, p<.05)$. Although 
research showed students were stressed with continuously learning through online classes, the results showed that it was not a major challenge for students. Cao et al (2020) and Rehman et al (2020) shared students around the globe experiencing adversity completing their group assignments and the dubiousness of examinations in their universities. Some students were seen reporting on affordability challenges in sourcing online devices to engage in online learning. This undoubtedly contributed to added stress which had dire consequences on their academic performance (Cao et al., 2020; Rahman, 2020).

\section{Research Question 3}

\section{Is there any relationship between students' mental health and academic performance?}

Stress has always been an issue among students, and was significantly correlated to academic achievement (Ahmed et al., 2020; Reddy et al., 2018). The Tukey post-hoc test also indicated that all participants are stressed sitting for their examination especially during MCO. However, students obtained 2.50 to 2.99 CGPA are more stressed with a mean -.5098* compared to students with 3.50-4.00 CGPA with .5098*. Perhaps students with higher CGPA have revised their lessons and are more prepared for their examination. We can therefore conclude students with higher CGPA were less stressed compared to those who obtained lower grades. The findings corroborated with McArdle et al (2014) who affirmed students who scored higher grades are less stressed compared to students that did not perform to a satisfactory standard.

Table 5: Relationship between Stress and CGPA

\begin{tabular}{|l|c|c|}
\hline \multicolumn{2}{|c|}{ Academic Achievement } \\
\hline \multirow{3}{*}{ Stress } & Pearson correlation & 0.195 \\
\cline { 2 - 3 } & Sig. (2-tailed) & 0.000 \\
\cline { 2 - 3 } & $\mathrm{N}$ & 300 \\
\hline
\end{tabular}

The analysis of regression showed the higher the level of stress, the lower the academic performance. However, the relationship between stress and academic performance seems to have only a statistically significant effect on students' mental health. Table 6 illustrates the relationship between stress and academic achievement is negative and weak ( $r=-0.19)$. Results indicated stress is shown to be significantly correlated to academic achievement $(p=0)$. Such statement can be supported as both have the same result with one another. From the table, it shows that there is a correlation between types of university with stress level among undergraduates because $p=-0.102<0.05$. This indicated participants from public and private universities corroborate that academic commitment is stress inducing. This was consistent with Abdullah et al. (2020) who found the higher the level of stress, the more troubled the students will be in completing their assignments, which can ultimately diminish their academic performance and educational experience. 
INTERNATIONAL JOURNAL OF ACADEMIC RESEARCH IN PROGRESSIVE EDUCATION AND

DEVELOPMENT

Vol. 10, No. 2, 2021, E-ISSN: 2226-6348 @ 2021 HRMARS

Table 6: Correlation between Stress and Academic Achievement

\begin{tabular}{|c|c|c|c|c|}
\hline $\begin{array}{l}\text { Dependent } \\
\text { Variable }\end{array}$ & Current CCPA & Current CCGPA & $\begin{array}{c}\text { Mean } \\
\text { Difference (I-J) }\end{array}$ & Sig. \\
\hline \multirow{12}{*}{$\begin{array}{l}\text { Academic work } \\
\text { causes stress }\end{array}$} & \multirow{3}{*}{2.00 to 2.49} & 2.50 to 2.99 & .085 & .99 \\
\hline & & 3.00 to 3.49 & .37 & .72 \\
\hline & & 3.50 to 4.00 & .59 & .34 \\
\hline & \multirow{3}{*}{2.50 to 2.99} & 2.00 to 2.49 & -.08 & .99 \\
\hline & & 3.00 to 3.49 & .28 & .35 \\
\hline & & 3.50 to 4.00 & $.51^{*}$ & .03 \\
\hline & \multirow{3}{*}{3.00 to 3.49} & 2.00 to 2.49 & -.37 & .72 \\
\hline & & 2.50 to 2.99 & -.28 & .35 \\
\hline & & 3.50 to 4.00 & .22 & .42 \\
\hline & \multirow{3}{*}{3.50 to 4.00} & 2.00 to 2.49 & -.59 & .34 \\
\hline & & 2.50 to 2.99 & $-.51^{*}$ & .03 \\
\hline & & 3.00 to 3.49 & -.22 & .42 \\
\hline
\end{tabular}

Besides ensuring that the students are developed in both cognitive and psychological aspects, this study also helps in considering the need of designing stress interventions for the students as non-face-to-face teaching and learning process is expected to continue till end of the year. It will be helpful for students if they can be guided to reduce their stress levels as to facilitate their academic achievement.

\section{Conclusion}

The findings in our study indicated students within Malaysian public and private universities were profoundly affected during the lockdown, resulting in diminished mental states. Remote learning being foreign for many and needing to accommodate new learning styles in a short span of time contributed to accentuated anxiety and stress. This was detrimental to the academic performance of students.

Several lacunae were identified in our study. Given our study was quantitatively determined, it would be useful to consider the subjective realities of students pertaining to the effects of the pandemic and lockdown coupled with experiences of remote learning through a qualitative research modality. Students residing in rural areas were seen reporting internet unavailability and internet unreliability issues. These students were mostly disadvantaged from remote learning. Many even failed as a result of this. Future research could explore the accessibility of remote learning among students living in metropolitan and especially, rural areas within a Malaysian context. This is to ensure students are treated equitably and during times of crisis, more flexibility and personalization is made by educators in how students access the learning content and are being assessed. Moreover, research and ongoing development on the internet infrastructure in Malaysia is also warranted.

\section{Pedagogical Implications}

Since the study focuses on the mental stress of undergraduates in Malaysia, the findings will help the higher learning institutions in Malaysia to understand the factors causing stress to students and take steps to address the challenges. It was understood that lack of social context and learning environment along with continuous assignments, have added to undergraduates' stress. Additionally, remote learning has proven to be one of the crucial 
factors causing mental stress among students. Hence, improved pedagogical practices need to be established to better support the mental health needs of students especially during this pandemic where students have generally been learning in isolation. Students who are not socially in contact with peers and friends (Kshirsagar \& Seema, 2016) and detached from the usual classroom learning environment (Garrison, 2009) are also prone to experience mental stress (Abdullah et al., 2020; Hidayu \& Vasudevan, 2020). Besides, Malaysian undergraduates who perpetually accomplishing assignments, assessments and examination were found to exhibit an increased level of anxiety and stress (Shahzad et al., 2020).

There is a need to raise more awareness and humanize mental health challenges as a universal human experience within non-western countries. By upholding such mentality, we can better understand the students we support in aspects of life, personal and professional domains. An implication of this for higher learning curriculum designers and educators is the need to find and adapt appropriate approach, focusing on integrative and collaborative skills required for ODL that cater to the needs of these undergraduates so that they can help them learn with less mental stress.

In order to ensure the mental well-being of undergraduates participating in ODL, future research could explore academic and professional staff working within higher education settings on their perceptions of mental health to discern the stigmas and prejudices within the Malaysian context. This is especially prevalent within some cultures and religions in Malaysia, where mental health is seen as an incurable disease and pathologized (Hassan et al., 2018). Whilst educators did their best in supporting students with transitioning to remote learning, they were not necessarily equipped or trained in responding to the mental health needs of the students.

\section{Reference}

Abdullah, S. F., Shah, N. A., \& Idaris, R. M. (2020). Stress and its relationship with the academic performance of higher institution students. International Journal of Advanced Research in Education and Society, 2(1), 61-73. Retrieved from http://myjms.mohe.gov.my/index.php/ijares/article/view/8844/3955

Agha, E. (2021). Learning rebooted: online education during Covid-19 lockdown puts spotlight on India's digital divide. https://www.news18.com/news/india/learning-rebootedonline-education-during-covid-19-lockdown-puts-spotlight-on-indias-digital-divide2563265.html

Ahmed, H., Allaf, M., \& Elghazaly, H. (2020). COVID-19 and medical education. The Lancet Infectious Diseases. 20(7), 777-778. https://doi.org/10.1016/S14733099(20)30226-7

Baptista, M. N., Carneiro, A. M., \& Cardoso, H. F. (2014). Depression, family support and hopelessness: a correlated study. Universitas Psychologica, 13(2), 693-702. https://doi.org/10.11144/Javeriana.UPSY13-2.dfsh

Banerjee N. C., \& Chatterjee, I. (2016). Academic stress suicidal ideation and mental wellbeing among $1^{\text {st }}$ semester \& $3^{\text {rd }}$ semester medical, engineering \& general stream students. Journal of Arts, Science and Commerce, 7(3), 73-80. https://doi.org/10.18843/RWJASC/V7I3/09

Boulton, M., \& O'Connell, K. A. (2017). Nursing students' perceived faculty support, stress, and substance misuse. Journal of Nursing Education, 56(7), 404-411. https://doi.org/10.3928/01484834-20170619-04. 
Cao, W., Fang, Z., Hou, G., Han, M., Xu, X., Dong, J., \& Zheng, J. (2020). The psychological impact of the COVID-19 epidemic on college students in China. Psychiatry Research, 287(0), 1-6. https://doi.org/10.1016/j.psychres.2020.112934

Calvarese, M. (2015). The effect of gender on stress factors: an exploratory study among university students. Social Science, 4(4), 1177-1184.

https://doi.org/10.3390/socsci4041177

De Brier, N., Stroobants, S., Vandekerckhove, P., \& De Buck, E. (2020). Factors affecting mental health of health care workers during coronavirus disease outbreaks: a rapid systematic review. PLoS One, 15(12), 1-19.

https://doi.org/10.1371/journal.pone.0244052

Dhawan, S. (2020). Online learning: a panacea in the time of COVID-19 crisis. Journal of Educational Technology Systems, 49(0), 5-22. https://doi.org/10.1177/0047239520934018

Elmer, T., Mepham, K., \& Stadtfeld, C. (2020). Students under lockdown: comparisons of students' social networks and mental health before and during the COVID-19 crisis in Switzerland. PLOS One, 15(7), 1-22. https://doi.org/10.1371/journal.pone.0236337

Hassan, M. F., Hassan, N. M., Kaasim, E. S., \& Hamzah, M. I. (2018). Issues and challenges of mental health in Malaysia. International Journal of Academic Research in Business and Social Sciences, 8(12), 1685-1696. https://doi.org/10.6007/IJARBSS/v8-i12/5288

Hidayu, F., \& Vasudevan, H. (2000). Covid-19 pandemic during 2020 Malaysia movement control order (MCO) - the case of residential college students' mental health. CnR's International Journal of Social \& Scientific Research, 6(11), 1-7.

https://www.researchgate.net/publication/343102659

Garrison, D. R. (2009). Communities of inquiry in online learning: social, teaching and cognitive presence. In C. Howard et al. (Eds.), Encyclopedia of distance and online learning (2nd ed., pp. 352-355). Hershey.

Garrison, D. R. (2007). Online community of inquiry review: social, cognitive, and teaching presence issues. Journal of Asynchronous Learning Networks, 11(1), 61-72. https://doi.org/10.24059/olj.v11i1.1737

Gorsky, P., \& Blau, I. (2009). Online teaching effectiveness: a tale of two instructors. The International Review of Research in Open and Distributed Learning, 10(3), 1-27. https://doi.org/10.19173/irrodl.v10i3.712

Gopalkrishnan, N. (2018). Cultural diversity and mental health: considerations for policy and practice. Frontiers in Public Health, 6(179), 1-7. https://doi.org/10.3389/fpubh.2018.00179

Kshirsagar, R., \& Seema, A. (2016). A conceptual framework on stress among undergraduate students: a literature review. International Journal of Management, IT and Engineering, 6(8), 1-9. https://www.researchgate.net/publication/307475322

Islam, M. A., Barna, S. D., Raihan, H., Khan, M. N. A., \& Hossain, M. T. (2020). Depression and anxiety among university students during the COVID-19 pandemic in Bangladesh: a web-based cross-sectional survey. PloS One, 15(8), 1-12.

https://doi.org/10.1371/journal.pone.0238162

Liu, G., Zhang, M., Chen, X., Zhang, W., Ding, W., \& Zhang, Q. (2015). Evolution of threonine aldolases, a diverse family involved in the second pathway of glycine biosynthesis. Journal of Molecular Evolution, 80(2), 102-107. https://doi.org/10.1007/s00239-015-9667-y 
Luo, M., Guo, L., Yu, M., \& Wang, H. (2020). The psychological and mental impact of coronavirus disease on medical staff and general public: a systematic review and metaanalysis. Psychiatry Research, 291(0), 1-10.

https://doi.org/10.1016/j.psychres.2020.113190

Lowenthal, P., Borup, J., West, R., \& Archambault, L. (2020). Thinking beyond zoom: using asynchronous video to maintain connection and engagement during the COVID-19 pandemic. Journal of Technology and Teacher Education, 28(2), 383-391. https://www.researchgate.net/publication/344468538

McArdle, J., Hamagami, F., Chang, J. Y., \& Hishinuma, E. S. (2014). Longitudinal dynamic analyses of depression and academic achievement in the Hawaiian high schools health survey using contemporary latent variable change models. Structural Equation Modeling, 21(4), $608-629$. https://doi.org/10.1080/10705511.2014.919824

Mian, A., Khan, S. (2020). Medical education during pandemics: a UK perspective. BMC Medicine, 18(1), 103. https://doi.org/10.1186/s12916-020-01577-y

Qiu, J., Shen, B., Zhao, M., Xie, B., \& Xu, Y. (2020). A nationwide survey of psychological distress among Chinese people in the COVID-19 epidemic: implications and policy recommendations. General Psychiatry, 33(2). https://doi.org/10.1136/gpsych2020-100213

Roddy, C., Amiet, L. D., Chung, J., Holt, C., Shaw, L., McKenzie, S., Garivaldis, F., Lodge, J. M., \& Mundy, M. E. (2017). Applying best practice online learning, teaching, and support to intensive online environments: an integrative review. Frontiers in Education, 2(59), 110. https://doi.org/10.3389/feduc.2017.00059

Raj, U., \& Fatima, A. (2020). Stress in students after lockdown due to COVID-19 threat and the effects attending online classes. SSRN Electric Journal, 1-9. https://doi.org/10.2139/ssrn.3584220

Rashid, A. A., Rashid, A.M. R., Yaman, M. N., \& Mohamad (2020). Teaching medicine online during the COVID-19 pandemic: a Malaysian perspective. Bangladesh Journal of Medical Science, 19(0), 1-5. https://doi.org/10.3329/bjms.v19i0.48170

Rehman, U., Shahnawaz, M. G., Khan, N. H., Kharshiing, K, D., Khursheed, M., Gupta, K., Kashyap, D., \& Uniyal, R. (2020). Depression, anxiety and stress among Indians in times of Covid-19 lockdown. Community Mental Health Journal, 57(0), 42-48. https://doi.org/10.1007/s10597-020-00664-x

Reddy, K. J., Menon, K. R., \& Thattil, A. (2018). Academic stress and its sources among university students. Biomedical and Pharmacology Journal, 11(1), 531-537. https://doi.org/10.13005/bpj/1404

Rahman, A. P. (2020). Isolation and mental health: the psychological impact of lockdown. https://www.thehindu.com/society/isolation-and-mental-health-the-psychologicalimpact-of-lockdown/article31237956.ece

Shahzad, A., Hassan, R., Aremu, A. Y., Hussain, A., \& Lodhi, R. N. (2020). Effects of COVID-19 in E-learning on higher education institution students: the group comparison between male and female. Quality \& Quantity, 55(2), 805-826. https://doi.org/10.1007/s11135020-01028-z

Siraj, H., Salam, A., Roslan, R., Hasan, N, A., Jin, T. H., \& Othman, M. N. (2014). Stress and its association with the academic performance of undergraduate fourth year medical 
students at Universiti Kebangsaan Malaysia. International Medical Journal Malaysia, 13(1), 19 -24. https://doi.org/10.7324/JAPS.2014.41209

Stults-Kolehmainen, M. A., \& Sinha, R. (2014). The effects of stress on physical activity and exercise. Sports Medicine, 44(1), 81-12. https://doi.org/10.1007/s40279-013-0090-5

United Nations Educational, Scientific and Cultural Organization (UNESCO). (2020, Feb 1). https://en.unesco.org/covid19/educationresponse

Vanclay, F., Baines, J. T., \& Taylor, C. N. (2013). Principles for ethical research involving humans: ethical professional practice in impact assessment Part I. Impact Assessment and Project Appraisal, 31(4), 243-253. https://doi.org/10.1080/14615517.2013.850307

Veena, N., \& Shastri, S. (2016). Stress and academic performance. The International Journal of Indian Psychology, 3(4), 71-82. http://oaji.net/articles/2016/1170-1462485066.pdf

Wang, C., Pan, R., Wan, X., Tan, Y., Xu, L., Ho, C. S., Ho, R. C. (2020). Immediate psychological responses and associated factors during the initial stage of the 2019 coronavirus disease (COVID-19) epidemic among the general population in China. International Journal of Environmental Research and Public Health, 17(5), 1-25. https://doi.org/10.3390/ijerph17051729

Yau, Y. H. C., \& Potenza, M. N. (2013). Stress and eating behaviors. Minerva Endocrinol, 38(3), 255-267. https://www.ncbi.nlm.nih.gov/pmc/articles/PMC4214609/

YoungMinds. (2020). Coronavirus: Impact on young people with mental health needs. https://youngminds.org.uk/media/3708/coronavirus-reportmarch2020.pdf

Zhai, Y., \& Du, X. (2020). Addressing collegiate mental health amid COVID-19 pandemic. Psychiatry Research, 288(0), 1-2. https://doi.org/10.1016/j.psychres.2020.113003 